\title{
Metamorphosis of Engineering Education by Entrepreneurship in the field of Human Resource Development (HRD)
}

\author{
S. K. Jha \\ Division of Instrumentation and Control Engineering, \\ NSIT, Dwarka, New Delhi. \\ jhask271@gmail.com
}

\begin{abstract}
World over there is no dearth of entrepreneur in the field of Industry but there is dearth of entrepreneurship in the field of Human Resource Development (HRD). Due to lack of soul stirrer in the form of human resource developer many otherwise innocent engineer, technocrats and scientists are joining terrorist organization all over the world which is a matter of great concern. Thinking process of many great souls have culminated that HRD entrepreneurship to create human capital is even more important than industrial entrepreneurship. In order to have holistic development of society perfect symbiosis between industrial entrepreneurship \& HRD entrepreneurship is required. In the absence of this symbiosis, life is only robotized and may lead to catastrophe \& cataclysm. Even after fair degree of development in the field of science and technology, the way sectarianism, bigotry and jingoism etc. is raising its ugly head, it may in no time engulf the vibrant civilizations. The main purpose of this paper is to highlight the need of engendering human entrepreneur who could stir up the conscience of the masses to follow the righteous path. Notwithstanding the ubiquitous and phenomenal development in the field of science and technology, nothing can practically serve the purpose without ethical and moral development of human resources and hence the new terminology 'HRD entrepreneur' has been coined and explained in this paper. Fair example may be that of Gandhi, Vivekananda, Jesus Christ, Buddha, etc. as HRD entrepreneur. Vivekananda's Chicago address stirred up the conscience of western thinkers and many became his followers and thus heralded a new concept of HRD entrepreneurship. In order to scatter the feeling of altruism $\&$ philanthropism, human resource development in terms of spiritual tenets along with science and technology is
\end{abstract}

\footnotetext{
S. K. Jha

Division of Instrumentation and Control Engineering,

NSIT, Dwarka, New Delhi.

jhask271@gmail.com
}

indispensable.

Keywords: HRD Entrepreneur, Science and Technology, Swami Vivekananda, Mahatma Gandhi, Swami Prabhupada, Science, Spirituality, Symbiosis

\section{Introduction}

There has been tremendous growth in field of science and technology and has made quantum jump in every walk of life [1-16]. With the help of science we are able to accomplish our task in the twinkling of on eye. Hundred years ago if anybody would have talked about the form of science what is visible in present time, it would have looked as a day dreaming phenomenon. Many researchers have worked in the field of modern technology such as robust and optimal control field [1-9]. Hitherto very least endeavour has been made in the direction of understanding the spiritual implication of robustness and optimality in context with human as a system.

Human being is the most subtlest and complex creation in the world. Though applying all these modern scientific form of robust and optimal controller, we are able to control different complex system, yet the very purpose of leading a contented and peaceful life is not addressed. After all the basic purpose of incredible development in the field of science and technology ought to be to establish peace and harmony in the world but unfortunately that is not visible. In order to establish peace and harmony in the world the perfect understanding of intertwined link between the scientific and spiritual implication these modern form of controllers which is not possible unless and until there will be collaboration between scientific and spiritual entrepreneur. Amalgamation of scientific and spiritual entrepreneur is coined here to be known as HRD entrepreneur.

A scientific controller designed for any system is said to be robust and optimal if it is able to work optimally under parametric uncertainties i.e. under changed circumstances of nature. The scientific implication of 
giving optimal performance by any system lies in the fact that whether designed system accomplishes the task it is designed for by consuming least energy and time [1-9]. Similarly the spiritual implication of robust and optimal controller design for human being may be understood taking analogy from its scientific and technological counterpart. Spiritual entrepreneur has the capability to transform even perverted soul to great human being by applying their clairvoyant spiritual gumption. Though scientific, technological and industrial purpose has been solved by all these controllers but due to lack of ethics and spirituality, the very purpose of advance form of science is not solved. Ironically, nowhere we came across the spiritual implication of robust and optimal control in our day to day life.

From time immemorial, world over, the aboriginal peoples, unmindful of the scientific and technical implication of robust and optimal control, have made their physical bodies robust enough to take optimal performance out of it. On the contrary, these days, people have become completely dependent upon science and technology in every walk of life and thereby promoting more and more consumerism and for that matter the ecological disturbance due to environment pollution [19-24]. Here the spiritual entrepreneur may play pivotal role to think of the uses of science and technology in an ethical way and then ecological imbalances may be averted to a great extent.

Undoubtedly, science has made monumental progress but due to being devoid of ethical entrepreneurship sentiment, there is misuse of the byproduct of science. Unbridled population growth may also be ascribed one reason for this. Human resource development (HRD) entrepreneurship may play predominant role in curbing indiscriminate population growth as well as infusing ethical and spiritual temperament to the deviant minds [25-28]. In the epic Bhagwat Gita, a lot of emphasis is laid on maintaining equanimity of mind and its positive outcome is discernible in context with those who follow its injunctions elegantly laid out there. Unfortunately under parochial prejudices some school of thought is not able to address the population hazard that are hell bent on destroying the civilizations globally. Destruction of world trade tower of Amerika is glaring example of this unconscientious human population. Mahatma Gandhi has given special emphasis on holding fast and thereby maintaining celibacy and control of mind [27]. There are four things which are common between human being and animal: Eating, Sleeping, fear \& mating. Only thing which is not common is power of thought and spirituality. So science without spirituality will bring the human being closer to animal. HRD entrepreneur again may play pivotal role to end this bestiality and create conscientious human being [25-28].

Development of science and technology is irreversible process and very dangerous for ecology. Indiscriminate use of science has increased the pollution to a dangerously high level. With the increase of population a lot of deforestation is going on which virtually depletes the range of sanctuaries. With the effect of global warming ecological disturbance is discernible everywhere [19-24]. It is high time when scientists, technocrats, social activists and others need to ponder over the advantage and disadvantage of science and technology. People are going to be mechanical day by day. Their emotional and empathic quotient is waning day by day.

\section{Implication of Success and Role of HRD Entrepreneurs}

From time immemorial human being is striving diligently to be successful in every field of life. It is very crucial to understand the real meaning of being successful. When it is said that so and so became successful, it means they got success according to their own definitions of success. So getting success is nothing but just a matter of how the success is defined. Success of one person may not be regarded as a success of other person. It is very complex thing to explain. Success of one person may be failure for other person because he is having his own version of definition of success. Amidst these entire imbroglios, there appears a ray of hope to get the exact definition of success. Sometimes due to lack of good guide and teachers, peoples under quagmire of confusion and feel directionless.

History bears testimony to the fact that behind the success of every successful person, there is the role of his/her teachers or mentors. Teachers and mentors are required either directly or indirectly for achieving success. History is replete with both kinds of examples. In Indian history, Chandragupta got success under the inspiration \& direct tutelage of Chanakya. Vivekananda got success under direct inspiration of his teacher Ram Krishna Paramhansha. But there are also examples where the successful person became so not by direct tutelage but by indirect inspiration like Eklavya, Subhas Chandra Bose etc. When Dronacharya did not get ready to directly give teaching of archery to Eklavya, he took inspiration from his photo itself and became very great archer even braver than Arjuna. In the same way, Subhash Chandra Bose was very young when Swami Vivekananda was at his peak of name $\&$ fame in the field of spiritual awakening. When he grew older, he learnt about the mesmerizing spiritual and motivational power of Swami Vivekananda either by his elders or through the books. He got overwhelmed by the deep undercurrent of humanity propagated by Vivekananda and treated him as his spiritual guru and source of inspiration. This is also other example of success by indirect tutelage. Similar examples may be given from other part of the world also.

Different person get success according to their own definition of success. Bur for every success, a teacher or mentor is always required. Here different definitions of success from different perspective have been given and eventually it has been shown that true success may be envisaged only in terms of spiritual upliftment and awakening.

There are different ways by which peoples are defining success based upon their own perspective:

1. Some people define success in terms of professional development e.g. cracking prestigious exams, becoming ministers, CEOs of a particular company, getting PHD degrees etc.

2. Some negative people define success in terms of inflicting and creating pains to other person. 
3. Some person define the success in terms of how successful they are in exploiting the society by engendering the feeling of discriminations based on casteism, communalism, sectarianism etc.

4. Some people define success in terms of spiritual awakening i.e. in terms of the degree of universal brotherhood, philanthropism, altruism, patriotism, generosity, equanimity of mind and degree of contentment etc.

5. Some people define success in term of the degree of hatred, savagery, barbarism, tyranny, despotism, jingoism, animosity etc.

Being successful in negative direction also requires leaders and teachers, proficient in negative field in as much the same way as required in positive direction. So, in order to derive inspiration, whether positive or negative, it entails company of teachers having positivity or negativity accordingly.

Now the question arises as to what kind of success is good for bringing up the advance or exalted form of civilization? How the success be defined which is able to preserve the vibrant culture of the society? Obviously the 4th type of definition will only be able to preserve the vibrant culture of society in the world. Fifth type of definition of success is very dangerous and the person pursuing this definition of success may be hailed as incarnations of demons and scoundrels. So the fifth one is the worst kind of definition of success and the fourth one is the best form of definition of success. But ironically $90 \%$ of people of this world are not following the 4th type of definition of success, which entails intellectual sacrifices. Based upon the definition of success in in 5th type, hundreds of thousands of people are massacred in the name of pseudo religion and bigotry. Hence it need of time to mainly focus upon the 4th type of success. If we want to increase the numbers of successful persons under 4th type then good mentors and leaders are required who may set an example in society so that remaining can pursue their path accordingly. So, in other way round, we require numerous human resource development (HRD) entrepreneurs which may bring about paradigm turnaround by setting an example in the society and thereby creating good human capital.

\section{Some Examples of Human Resource Entrepreneurs}

\section{A.HRD Entrepreneur in the Form of Swami Vivekananda}

Discipline plays very pivotal role in the development of any country. In order to accomplish any task a tenacious resolution is required otherwise nothing may be fructified in the real sense. History of India gives glimpses of its pristine glory of the past. Past were glorious because great monks worked as a great spiritual HRD entrepreneur who contagiously produced many more similar humane entrepreneurs and one in that hierarchical order was Swami Vivekananda. With the self-abnegating approach he magnetically attracted many youths toward him and made them great human being. In Gita, Krishna says that normal people always follows and emulate the examples set by the great persons.

Even the western poet Longfellow in his famous poem Psalm of Life says that- "Lives of great man all remind us, we may make our lives sublime". In continuation he further writes - "A forlorn and shipwrecked brother, seeing shall take heart again". Those leaders who do not have harmony between words and deeds may not be a source of inspiration for the youths of the world. As the saying goes "don't scold the children if they don't follow you because they are always watching you". Vivekananda was a great exponent of rich cultural heritage of India. By way of his asceticism and austerity he stirred up the conscience of millions of youth and made country richer in HRD entrepreneur.

Great revolutionaries like Shubhash Chandra Bose always derived inspiration from his life. One girl from the western countries got overwhelmed by the tall spiritual personality of Swami Vivekananda and became his disciple and later on came to be known as Sister Nivedita. He is icon of millions of Indians who derive inspiration from his immaculate and impeccable leadership and play the role of second tier of HRD entrepreneurs.

\section{B.HRD Entrepreneur in the Form of Swami Prabhupada}

Just like Swami Vivekananda, Swami Prabhupada, a great exponent of the philosophy enshrined in Indian epics, worked as a great spiritual HRD entrepreneur and engendered so many devout followers and second and third generation HRD entrepreneurs. He worked with a missionary zeal to disseminate the tenets of Krishna consciousness to every nook and corners of the world. $\mathrm{He}$ founded International Society of Krishna consciousness (ISKCON) temple throughout the world. There are so many big industrialists who are great industrial entrepreneurs but they may not be regarded as HRD entrepreneur till they develop empathetic quotient in them. On the other hand there are so many big industrialists who are big industrial entrepreneur as well as HRD entrepreneur. Many big industrial entrepreneurs got converted to big HRD entrepreneur also when they came in contact with saint like Swami Prabhupada. Being devoid of spirituality many western people despite having affluent money were not leading happy and peaceful life. When they met with Swami Prabhupad who was repository of spiritual knowledge, got mesmerized and became his ardent followers and devotees.

\section{Other Examples of HRD Entrepreneur}

Because of lack of ethics and spirituality in common men and women, many measures taken by respective government are not redeemed in truest sense. So it is high time when leaders of different countries of the world need to focus undivided attention to create value added people in the society by taking recourse to the concept of HRD entrepreneurship. Best examples in these days are that of Malala Yusuf Jai of Pakistan \& Kailash Satyarthi of India 
who has worked tirelessly for the upliftment of marginalized section of society. Though the path is full of danger but it is also true that no good could be done without predicament and danger. So this path is path of sacrifice. In the same way the most inspiring HRD entrepreneur in the form of DasharathManjhi of Bihar came to light recently who single handedly accomplished the task of making roads through hills who is hailed as a major source of inspiration not only for millions of backward tribes but for millions of struggling youths of India.

Ravindranath Tagore also with the help of constructing patriotic poem tried to transform many disorganized youth into a nationalist and patriotic person. Mother Teresa is also the finest examples of HRD entrepreneur who worked for downtrodden and underprivileged peoples and left behind a chain of social entrepreneurs. Mahatma Gandhi by way of austerity and simplicity stirred up the conscience of millions of people in the world and gave birth to a new concept of nonviolence and passive resistance and thereby left behind uncountable followers. There are many more examples cutting across boundary lines whose endeavor in the field of creating value added HRD entrepreneur will go a long way in bringing about the turnaround in the world.

\section{Implication of HRD Entrepreneur Vis-À-Vis The World Peace}

Though harnessing of the benefits of HRD entrepreneurs is a global phenomenon, yet here the practical implication is illustrated in context with developing and third world countries like India and that may be extended and extrapolated for any other countries as well. In India basically job employments are in private and public sector. There is big difference between the methodologies of works between these two sectors. Same person when employed in private sector becomes disciplined and sincere towards their work but in government sector their attitude is different. Nobody is bothered to equip the employee with ethical and moral form of human resource development. In many government sectors there is no dispensation for proliferation of ethical and moral development in institute. For example in many technical institutions laboratories and equipment are there but due to lack of discipline and sense of belongingness, nobody is willing to deliver and the very purpose of outcome based education is not redeemed.

Similarly in other part of the world due to lack of true HRD entrepreneurs, science and technology is not utilized for betterment of human civilizations. A big competition is there who is superior to whom? There are many more problems which are increasing in magnitude day by day.

\section{A. Solution of this Problem}

Taking cognizance of the foregoing discussions the best solution may be that one subject on moral and ethical education be incorporated in technical institution all over the world extracting quintessential essence from different scriptures of all religions. This churning out process of every religious scripture will highlight the relative importance of one scripture from the standpoint of universal acceptance of ethical and moral aspect in the curriculum. In metropolitan cities, teaching of English subject as a language seems superfluous and redundant and in my view this ought to be replaced by the subject on 'moral and ethical education'. Because, in metropolitan cities, students are seen to be even more articulate and fluent in English than their teachers.

These days, in the name of appeasement, politicians world over are quite hesitant to promote true form of spirituality because of opposition from regressive people. This is very dangerous trend which if not taken seriously by world leaders, may invite cataclysm for coming generation. The world is safe till the sophisticated arms and ammunitions are in the hand of good and morally uplifted people but what will happen if same goes in hand of rogue elements. In the days to come it may very well be conjectured (seeing the present trends of demographic population growth rate) that good and ethical peoples will be outnumbered and hence overpowered by bad and rogue peoples and hence the visit of doomsday and apocalypse is certain. Hence it is high time to ponder over seriously to forcefully recognize and incorporate the true quintessential essence of science of spirituality in curriculum to save this world from annihilation otherwise it will be too late to mend. It is appropriate here to cite what Swami Vivekananda said in parliament of religion held at Chicago in Amerika in 1893.

"Sectarianism, bigotry, and its horrible descendant, fanaticism, have long possessed this beautiful earth. They have filled the earth with violence, drenched it often and often with human blood, destroyed civilization and sent whole nations to despair. Had it not been for these horrible demons, human society would be far more advanced than it is now. But their time is come; and I fervently hope that the bell that tolled this morning in honour of this convention may be the death-knell of all fanaticism, of all persecutions with the sword or with the pen, and of all uncharitable feelings between persons wending their way to the same goal".

It is high time to redeem the dream of Vivekananda by following his mantra for establishing peace in the world.

\section{Holistic and Pragmatic Implication of HRD Entrepreneur}

If we extend the concept of HRD entrepreneurship further, many difficult problems may be solved. For instance, if we take example of Pakistan, it seems very difficult to resolve many issues but it may be resolved by capturing the attention of forward looking ambitious Pakistanis. If India and Pakistan keep making stereotype image of each other, solution will be elusive. In fact the root cause of hatred between India and Pakistan is religion and culture mismatch. In fact religion should be judged based upon their acceptability in terms of spirituality. We need to disseminate the tenets of our philosophy to the world in a fruitful way. If bad things have ripple effects so do have good things. By creating HRD entrepreneurs and there by spreading the message of great leaders across the border may have contagious effect. We should rope in good people across the border who may work as conduit for dissemination of spiritual approach to solve the outstanding problems. Given the rich cultured heritage, India \& 
Pakistan may solve many problems by cultural \& spiritual assimilation and not by nuclear invasion.

Former President of India, A. P. J. Abdul Kalam was a great visionary and was the best example of scientific and HRD entrepreneur who transcending the parochial religious boundary line, tried to create harmony between science and spirituality. Gandhi, following the value added HRD entrepreneur, shook the material shackle of British rule.

Human is the only animal which has characteristics of the entire animals. Some animals are barbaric in nature and some are peaceful and some are in between. Animal has some limitation of their behavioural pattern. Company cannot make too much change in their behavioural pattern unlike human being. Due to religion, scriptures or company, man can become either God or demon. It all depends upon the illustration of the thing. Many people illustrate the same thing in different way. So we require having healthy debate and discourse as to the acceptance and assimilation of only that part of religious scriptures which promotes humility and humanity. In order to become good human resource, one need to be irreligious and he or she should be given freedom to choose religion based upon the spiritual substance in that religion that is good for human civilization.

When we study science we forget about what religion or country we belong to. We only see the contents and we prefer that science books which contains maximum portion of our syllabus and are easy to be understood. In the same way when we fall sick, we search the best doctor irrespective of their ethnic or regional background. Spirituality is as much necessary for human being as science is. Spirituality is something which may bring about transcendental change in our life pattern. If a person is spiritual he has high degree of empathy \& humanity. Spirituality is antidote to hatred-ness, bigotry and hypocrisy. So whatever religion one belong to one should make analogy between religion and science books (or that of good doctors) and try to assimilate spiritual content from any religion irrespective of which religion one is born in. One must then appreciate the different religion based on itsits spiritual contents only. This approach will no doubt herald the harbinger of advance form of civilization.

\section{Conclusions}

In this paper the new phraseology in the form of HRD entrepreneurship has been coined and its useful implication vis-a-vis human civilization has been explained. Development of scientific and industrial entrepreneurship will do no good if not supported with value added HRD entrepreneurship. The meaning of HRD entrepreneurship is to produce such human being who is full of spiritual and empathetic quotient. World over there is no dearth of entrepreneur in the field of Industry but there is dearth of entrepreneurship in the field of human resource development (HRD). Due to lack of soul stirrer in the form of human resource developer in every religion, many otherwise innocent engineer, technocrats and scientists are joining terrorist organization all over the world which is a matter of great concern. Thinking process of many great souls may culminate the fact that HRD entrepreneurship is even more important than industrial entrepreneurship. In order to have holistic development of society perfect symbiosis between industrial entrepreneurship and HRD entrepreneurship is required. In the absence of this symbiosis, life is only robotized and may lead to catastrophe \& cataclysm. Even after fair degree of development in the field of science and technology, the way mutual animosity, bigotry, jingoism etc. is raising its ugly head, it may in no time engulf the vibrant civilizations. Therefore, the main purpose of this paper is to highlight the need of engendering human entrepreneur who could stir up the conscience of the masses to follow the righteous path. Through many examples of pragmatic and empathetic HRD entrepreneur it may be inferred that in order to sprinkle the feeling of altruism \& philanthropism, human resource development in terms of spiritual tenets is indispensable for heralding the advance form of civilization.

\section{Acknowledgement}

The author wish to pay obeisance to the ancient order of monks of India and its rich cultural heritage which gave inspiration to ruminate over such topics which is indispensable and invaluable for mankind. Due thanks are also to numerous dedicated scientist and saints of other parts of the world but for whom the topic like HRD Entrepreneurship and its implication for creation of better of civilization wouldn't have been possible.

\section{References}

[1] Jha,S. K. Yadav,A.K. Gaur,Prerna and Gupta, J.R.P (2014) "Robust Stability Analysis of DC Servo Motor for Attitude Control of Aircraft using Arguon's Theorem," Journal of Control Engineering and Technology, vol. 4, issue 2, pp. 127-134.

[2] Tan,N. and Atherton,D. P. (2000) "Stability, and performance analysis in an uncertain world," IET Comput. Control Eng. J., vol.11, no.2, pp.91-101.

[3] Bhattacharyya,S. P., Datta,Aniruddha, and Keel,L. H. (2009) "Linear Control Theory: Structure, Robustness and Optimization", CRC Press, Taylor and Francis Group, New York.

[4] Doyle,J. C. and Stein, G.(1981) "Multivariable Feedback Design: Concepts for a Classical/Modern Synthesis," IEEE Transaction on Automatic Control, AC- 26 (1), pp. 4-16.

[5] Jha, S. K. Yadav, A. K. Gaur, Prerna. Parthsarathy, H. and Gupta, J.R.P. (2014), "Robust and Optimal Control Analysis of Sun Seeker System," Journal of Control Engineering and Applied Informatics, Vol.16, No.1, pp. 70-79.

[6] Yadav,A.K. Gaur, Prerna. Jha,S. K. Gupta, J.R.P. and Mittal, A. P. (2011), "Optimal Speed Control of Hybrid Electric vehicle," Journal of Power Electronics, vol. 11, no. 4, pp. 393-400.

[7] Kirk, D.E. (1970)Optimal Control Theory: AN INTRODUCTION,Prentice Hall, Englewood cliffs, New Jersey.

[8] Keel,L. H. and Bhattacharyya,S. P. (1997) "Robust, Fragile or Optimal?," IEEE Trans. Automat. Contr., vol. AC-42, no. 8, pp. 1098-1105.

[9] Jha,S. K. Parthsarathy,H. Gupta,J. R. P. and Gaur,P. (2011), "Verification of the Veracity of Brachistochrone Curve and Evolution of Optimal 
Control," India International Conference on Power Electronics (IICPE), N. Delhi, India, pp. 1-4.

[10] Ogata, K. (1997),Modern Control Engineering, Prentice Hall, USA, Third Edition, 1997.

[11] Richardson,K. I. T. (1954) "The Gyroscope Applied," The Philosophical Library, New York, pp. 261-264.

[12] McRuer,D. and Graham,D. (1981) "Eighty Years of Flight Control: Triumphs and Pitfalls of the System Approach," Journal of Guidance and Control, vol. 4.

[13] Kuo,B. C. and Golnaraghi,Farid (2003) Automatic Control System, John Wiley and Sons (Asia) Pte Ltd, Eighth Edition.

[14] Zadeh, L. A. (1984) "Making computer think like people," IEEE Spectrum, 21, pp. 26-32.

[15] Pushpkant and Jha,S. K. (2013) "Performance Analysis of Conventional, Modern and Intelligent Control Techniques for Controlling CNC Machine Tool," International Journal of Applied Engineering Research, vol. 8, no. 6, pp. 51-55.

[16] Tan,N. and Atherton,D. P. (2000) "Stability and performance analysis in an uncertain world," Computing and Control Engineering Journal, pp. 91101.

[17] Jha, S. K. Yadav, A. K. Gaur, Prerna. Parthsarathy, H. and Gupta, J.R.P. (2014), "Robust and Optimal Control Analysis of Sun Seeker System," Journal of Control Engineering and Applied Informatics, Vol.16, No.1, pp. 70-79.

[18] Yadav, A. K. and Gaur,P. (2013) "Comparative analysis of modern control and AI-based control for maintaining constant ambient temperature," World Review of Science, Technology and Sustainable Development, vol. 10, Nos. 1/2/3, pp. 56-77.

[19] Husain,Iqbal (2011) Electric and Hybrid Vehicles, Design Fundamentals (2nd edition), CRC Press, Taylor and Francis Group, New York.

[20] U.S. Environmental Protection Agency (EPA), (1994) "Automobile emissions: An overview," EPA 400-F92-007, Fact Sheet OMS-5.

[21] Doniger,D. Friedman,D. Hwang, R. Losof,D. and Mark,J. (2002) "Dangerous Addiction: Ending America's Oil Dependence," National Resources Defense Council and Union of Concerned Scientists.

[22] Ehsani, M. Gao, Y. and Emadi,Ali (2011) Modern Electric, Hybrid Electric, and fuel Cell VehiclesFundamentals, Theory, and Design, ${ }^{\text {nd }}$ Edition, CRC Press, Florida.

[23] Larminie,J. and Lowry,J. (2012)Electric Vehicle Technology Explained, John Wiley \& Sons, U.K.

[24] Jha,S. K. and Jha,R. (2012) "Investigating The Indispensability of Renewable Energy Sources from the Standpoint of Conservation of Ecology and Environment," Invertis Journal of Renewable Energy, vol. 2, no. 4, pp. 219-233.

[25] Times of India, Speaking Tree, Sunday times sources.

[26] Srimadbhagwadgita sources.

[27] An Autobiography of Gandhi: The Story of My Experiment With Truth.

[28] Jha, S. K. (2015)“Transforming Engineering Education Exploiting Inveterate Symbiosis Between Science and Spirituality," Journal of Engineering Education Transformation (JEET), Vol. 29, issue 2, pp. 25-30. 